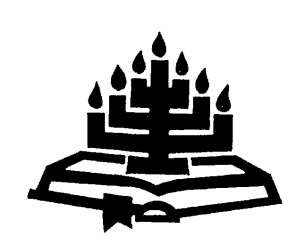

\title{
Vyandigheid in apokaliptiese literatuur - die Daniëlboek
}

\author{
Marius Nel \\ Skool vir Bybelwetenskappe en Bybeltale \\ Potchefstroomkampus \\ Noordwes-Universiteit \\ POTCHEFSTROOM \\ E-pos: mariusnel1@mweb.co.za.
}

\begin{abstract}
Animosity in apocalyptic literature - the Book of Daniel

What is reflected in apocalyptic literature about the subject of animosity? Apocalyptic literature is limited in this article to the Book of Daniel, because it is the most extended apocalyptic text in the Old Testament. Before an apocalyptic work can be discussed, it is important to answer several preliminary questions: what is apocalyptic literature, and what is the phenomenon of apocalypticism? What are the characteristics of this genre? And what are the socio-historical origins of apocalyptic movements?
\end{abstract}

To understand the Book of Daniel, it is imperative to discuss the two "Sitze im Leben" present in the development of the book. These "Sitze" are the supposed sixth-century BCE exile of Judah, and the second-century BCE Jewish persecution under the Syrian king, Antiochus.

The patterns of animosity in the Book of Daniel are discussed in terms of the relationship between God and people; Jews and a foreign king; Jews and their neighbours; and two groups operating in the Jewish community according to apocalyptic perception, believing and compromising Jews. The story of Daniel in the lion's den (Dan. 6) is used as a case study to demonstrate these patterns.

The conclusion of the study is that the tales (Dan. 1-6) and visions (Dan. 7-12) can only be understood properly in terms of the patterns of animosity present in the different plots behind the texts. 


\section{Opsomming}

\section{Vyandigheid in apokaliptiese literatuur - die Daniëlboek}

Wat sê apokaliptiese literatuur oor vyandigheid? Apokaliptiese literatuur word in hierdie artikel beperk tot die Daniëlboek, omdat dit die mees uitgebreide apokaliptiese teks in die $\mathrm{Ou}$ Testament is.

Om die Daniëlboek te verstaan, is dit noodsaaklik om die twee "Sitze im Leben" te bespreek wat in die ontstaan van die boek 'n rol gespeel het. Hierdie "Sitze" is die veronderstelde sesdeeeuse ballingskap van Juda, en die tweede-eeuse vervolging van die Jode onder koning Antiochus Epifanes van Sirië.

Patrone van vyandskap word in Daniël bespreek in terme van die verhouding tussen God en mense; tussen Jode en vreemde konings; tussen Jode en hulle bure; en tussen twee groepe wat in die Joodse gemeenskap betrokke was, wat volgens persepsies in apokaliptiese kringe bestaan het uit "gelowiges" en ander Jode wat 'n kompromis met die vyand aangegaan het. Die verhaal van Daniël in die leeukuil (Dan. 6) word gebruik om dié patrone te demonstreer.

Die gevolgtrekking van die ondersoek is dat die verhale (Dan. 1-6) and visioene (Dan. 7-12) eers ten volle verstaan kan word in terme van die patrone van vyandigheid wat teenwoordig is in die verskillende komplotte in die teks.

\section{Inleiding}

Die vraag wat in hierdie artikel gestel word, is: Watter rol speel vyandigheid in apokaliptiese literatuur in die Hebreeuse Bybel? Die Daniëlboek, die mees uitgebreide (alhoewel nie eksklusiewe) apokaliptiese teks in die Hebreeuse Bybel (Le Roux, 1988:2), word ondersoek om hierdie vraag te beantwoord.

In Daniël 1, 3, 4, 5, 6 en 9 word verhale vertel van Jode wat volhard in hulle geloof in $\mathrm{YHWH}$, en hoe hulle met voorspoed geseën word vanweë hulle volharding. Die vyandskap in hierdie verhale is tussen Jode wat getrou bly in hulle godsdiens en ongelowige konings en hofamptenare. Die verhale blyk om af te speel teen die agtergrond van die Joodse ballingskap wat volg op die beleërings van 598/597 en $588 / 587$ v.C. Die internasionale politieke toneel word oorheers deur Babilon en die beleid om nasies wat teen Babilon rebelleer, te verban. Babilonië integreer egter nie die verskillende groepe en nasies wat weggevoer word met mekaar nie, anders as wat die Assiriërs in die agste eeu v.C. met die Noordryk of Israel gedoen het. Die Babiloniese koning konfiskeer die voorwerpe in die tempel 
in Jerusalem wat aan JHWH gewy is. Hy ontheilig die tempel en vernietig die geboue. Die Judese koning word gevange geneem. Daniël 4 en 5 beskryf hoe die koning van Babilon deur JHWH gestraf word vir dié optrede wat van sy hubris getuig. In Daniël 9 word die terugkoms van die Jode uit ballingskap toegeskryf aan die bekering van hulle sondes, wat hulle verhouding met God beïnvloed het.

Daniël 2, 7, 8 en 10-12 bestaan uit visioene wat Israel se geskiedenis beskryf ná die ballingskap. Die doel is om die lesers van die Makkabese periode in die tweede eeu v.C. aan te moedig om te volhard in hulle geloof. Hierin word patrone van vyandskap beskryf in terme van Jode en hulle politieke vyande, sowel as van gelowige en ongelowige Jode, of Jode wat getrou aan hulle godsdiens gebly het en Jode wat gekompromitteer het. Die skrywer(s) van die Daniëlboek interpreteer "geloof" as lojaliteit aan die JHWH-kultus, as 'n direkte keuse téén Antiochus se helleniseringsbeleid. Die skrywer(s) beklemtoon God se invloed op die historiese gebeure. Die uiteindelike oplossing van vyandigheid bestaan in sy betrokkenheid by die geskiedenis, wanneer Hy in die "eindtye" party uit die dood laat opstaan om vir ewig te lewe en soos die sterre te skyn.

\section{Konteks van die boek van Daniël}

Om die Daniëlboek te verstaan, is dit noodsaaklik om die veronderstelde en werklike historiese kontekste, of Sitze im Leben na te vors. Terwyl die boek die indruk skep dat dit gedurende die sesde eeu v.C. afspeel, is die werklike agtergrond die tweede-eeuse vervolging van Jode wat Antiochus se helleniseringsbeleid teenstaan.

\subsection{Ballingskapsituasie: sesde eeu v.C.}

Nadat Israel in die agste eeu v.C. in ballingskap was, het Juda vir 'n eeu in die skadu van die konflik tussen die groot magte oorleef. Sanherib val Hiskia se Juda in 701 v.C. binne om Juda vir sy opstand teen Assirië te straf. Sanherib spog dat hy ses-en-veertig ommuurde stede, asook talle onbeskermde dorpies vernietig het, en 'n groot aantal mense - 200150 in totaal - asook baie diere weggevoer het. Net Jerusalem ontsnap aan sy wraak. Juda kon hulself nie bevry van die Assiriërs nie. Eers aan die einde van die sewende eeu was hulle vir 'n kort tydjie 'n vasal van Egipte (Ahlström, 1993:755). 
Babilon is die nuwe wêreldmag en Juda 'n vasal (Soggin, 1984:231). In 608 v.C. sterf Josia as hy probeer om Egipte te keer om Babilonië aan te val. Volgens die Kronis sowel as die Deutoronomis het Josia met ' $n$ proses begin om verheidensing hok te slaan wat in die regeringstye van Manasse en Amon hoogty gevier het. ${ }^{1}$ Die Daniëlboek funksioneer teen dié agtergrond. Die skrywer(s) veronderstel dat die vier Jode in Josia se tyd geleef het - 'n tyd van hervorming wanneer die boek van die wet "ontdek" word. 2

Josia se seuns regeer ná sy dood - Joahas word deur farao Nebo van Egipte van die troon verwyder en as gevangene in Ribla, in Hamat aangehou. Die farao plaas sy broer Eljakim op die troon. Hoekom die Egiptiese koning sy naam na Jojakim verander, is onbekend. Joahas sterf uiteindelik in Egipte. Jojakim onderwerp hom aanvanklik aan die Babiloniese koning, maar kom ná drie jaar in opstand. Babilonië reageer deur nie onmiddellik Juda aan te val nie, maar gebruik eerder roofbendes van onderhorige stamme en volke om Juda te straf.

2 Konings 24-25 vertel van twee deportasies van Jode deur die Babiloniërs. 2 Kronieke 36:6-7 veronderstel 'n derde deportasie, gedurende Jojakim se regeringstyd. Jojakim rebelleer in 601/600 v.C. teen Nebukadnesar, nadat hy hom vir drie jaar gedien het. Volgens die 2 Kronieke-verslag voer Nebukadnesar die koning en sommige van die tempelvoorwerpe weg. Daniël 1:1 dateer hierdie vermeende deportasie meer noukeurig, naamlik in Jojakim se derde regeringsjaar (606 v.C). Dié deportasie bring Daniël en sy vriende na die Babiloniese hof. Josefus (Ant. 10.96 e.v.) berig dat hierdie deportasie plaasgevind het in Jojakim se vyfde jaar, en dat drieduisend gevangenes weggevoer is, waaronder ook Esegiël.

Jeremia 52:30 vertel van nog 'n deportasie van 745 Jode deur Nebusaradan, in die drie-en-twintigste jaar van Nebukadnesar (582 v.C.). Dié deportasie is die gevolg van 'n strafekspedisie deur die

1 "To get a reliable picture from the 'devotional writings' of the Deuteronomic historian and the Chronicler is a frustrating task" (Ahlström, 1993:770).

$2 \quad$ Vir die problematiek wat hierdie hervorming behels, vergelyk Soggin (1984:243245) en Ahlström (1993:770-781). Bybelse skrywers gebruik 'n post-eksiliese godsdienstige model wat aan Hiskia en Josia die vestiging van 'n suiwer Jahwistiese godsdiens toeken. Dié twee konings sou dan teruggegaan het tot die veronderstelde primitiwistiese wortels van die $\mathrm{JHWH}$-godsdiens van Moses. Sommige moderne historici aanvaar hierdie model en verduidelik die Bybelse geskiedenis aan die hand daarvan, terwyl baie dit egter verwerp. 
Babiloniërs en volg op die moord van Gedalja. 'n Deportasie in die tyd van Jojakim, voor die Stryd van Karkemis in 605 v.C., is egter histories onwaarskynlik. Volgens die Babiloniese Kroniek het Nebukadnesar eers die volgende jaar in Juda aangekom. ${ }^{3}$ Die meeste navorsers verwerp vandag die moontlikheid van so 'n wegvoering (Albertz, 2003:75). Sedert die ontdekking van die Babiloniese Kroniek, kan argumente ten gunste van so 'n deportasie as weerlegbaar beskou word.

Jojakim word deur sy seun, Jojagin, opgevolg. Hy ontgeld die wraak van Babilonië oor sy pa se opstandigheid, en ná 'n beleg van drie maande gee hy oor. Sy straf is nie swaar nie, omdat hy gou oorgee. Hy word in 598/597 v.C. gevange geneem. 4 Nebukadnesar verwyder alle kosbaarhede uit die tempel en die paleis. Hy neem amptenare en soldate sowel as eenduisend opgeleide ambagsmanne gevange.

Jojagin se oom, Mattanja, word as koning oor Jerusalem aangestel in 597/596 v.C. Die Babiloniese koning verander sy naam na Sedekia. Hy regeer vir elf jaar. Jeremia 28 vertel van 'n antiBabiloniese komplot wat in Jerusalem gesmee word. In 590-589 v.C. rebelleer Sedekia teen die Babiloniese oorheersers, nadat hy 'n koalisie met ander volke gesluit het (Jer. 27-28). 2 Konings 25:1 vertel van dié Babiloniese beleg, waar die omliggende stede en dorpe verwoes word voordat Jerusalem ná 'n beleg van agtien maande verwoes word. Ou-Testamentiese bronne is dit eens dat die tweede deportasie in die elfde regeringsjaar van Sedekia plaasvind (2 Kon. 24:18; 25:2; Jer. 1:3; 39:2; 52:5). Oor die presiese datum, kan navorsers egter nie ooreenstem nie. Sommige plaas dit in 587 v.C., terwyl 'n groeiende tendens voorkom om die tweede deportasie eerder in 586 v.C. te plaas. ${ }^{5}$

3 Grayson (1975: Kroniek 5, obv. 15-20).

4 Die datum van die eerste deportasie is nie onder bespreking nie, omdat die inligting in die Babiloniese Kroniek (BM 21946) baie duidelik hieroor is. Die val van Jerusalem op die tweede Adar kom ooreen met 16 Maart 597 v.C. (Albertz, 2003:78).

5 Daar is drie redes vir die onsekerheid oor die datum. Eerstens breek die teks van die Babiloniese Kroniek af in 594/593, sodat geen buite-Bybelse gegewens vir die datum van die tweede deportasie bestaan nie. Die Bybel self gee ook teenstrydige datums: die negentiende jaar van Nebukadnesar (2 Kon. 25:8; Jer. 52:15), teenoor die agtiende regeringsjaar (Jer. 52:29). Derdens veroorsaak pogings om Judese en Babiloniese chronologieë te sinchroniseer probleme (Albertz, 2003:78-79). 
$\mathrm{Na}$ sewe-en-dertig jaar laat die koning van Babel, Ewil-Merodag, Jojagin vry en laat hom aan die koning se tafel eet (2 Kon. 25:27-30; Rendtorff, 1985:52-55).

Die val van Jerusalem beteken dat die Dawidiese regering na vierhonderd jaar beëindig word. Israel se monargie en onafhanklikheid kom tot ' $n$ einde. Eers in die tweede eeu v.C sou Juda (die Jode) hulle onafhanklikheid teruggekry, maar dan slegs vir 'n kort tydjie.

Die Daniëlverhale word doelbewus teen die agtergrond van die ballingskap geplaas, omdat die skrywer van die visioene die Babiloniese ballingskap as aansluitingspunt gebruik vir dit wat hy oor die Siriese krisis van die tweede eeu, wat Joodse bestaan bedreig, wil sê.

\subsection{Nuwe aktualiteit: tweede eeu v.C.}

Die tweede konteks van Daniël, waarin die verhale oorvertel en die gesigte bygevoeg word, is die vervolging van die Jode deur Antiochus IV. Dit is die grootste bestaanskrisis vir die Jode sedert die 587 v.C.-ramp.

Alexander die Grote verower Persië en verenig die oikoumene. As hy op die jong ouderdom van drie-en-dertig sterf sonder om 'n seun na te laat wat in staat is om in sy plek te regeer, gaan die mag aan sy vier generaals. Dus regeer die Ptolemeërs oor Egipte en die Seleukiede oor Sirië. Hulle veg vir die beheer oor Palestina. Die Joodse gemeenskap is verdeeld in hulle lojaliteit aan dié twee magte. Die invloedryke Oniad-familie onder Josef is lojaal aan die Ptolemeërs, alhoewel Josef die Seleukidiese Antiochus IV as die nuwe heerser erken. Die Tobiade weer, meen Hellenisme dien die saak van Judaïsme en steun Antiochus se pogings om Jode te ontwikkel.

Venter (1997:70-78) teken die Joodse gemeenskap van die tweede eeu in terme van twee groepe. Die arm mense produseer kos, terwyl die klein groepie rykes die gemeenskap organiseer om hulle te dien. Die elite groep bestaan uit die heerser en heersende klas, retensieklas, handelaars en priesters. Die groter groep bestaan uit die armes, werkers, onreines en vervangbares. Apokaliptiese literatuur, soos die Hemelvaart van Moses, 1 Henog 85-90 en Daniël het sy oorsprong in die magtelose retensieklas (Venter se term), terwyl die priesterlike aristokrasie die heersende politieke party ondersteun. 
Seleukus IV regeer oor Palestina van 187 tot 176 v.C., met verdraagsaamheid teenoor die Jode se eksentrieke godsdienstige gewoontes (vgl 2 Makk. 3:3; 4 Makk. 3:20). As Seleukus sy minister, Heliodorus, na Jerusalem stuur om belasting in te vorder, bring invloedryke Jode Onias III, die hoëpriester, in onguns. Onias reis na die koning se hof om homself te gaan verdedig.

Heliodorus vermoor Seleukus in 176 v.C. Seleukus se broer, Antiochus, volg hom op. Hy is juis op pad terug van Rome, waar hy as gyselaar aangehou is as deel van die straf vir sy vader se kolonialisasiebeleid. Antiochus kies die bynaam "Epifanes", moontlik omdat hy homself beskou as openbaring van die gode, of bloot as 'n retoriese middel. Die ortodokse Jode beleef dié bynaam egter as uitdagend (Soggin, 1984:292). Antiochus se muntstukke dra die beeld van Zeus Olimpos, wat verdag baie na Antiochus se gelaatstrekke lyk.

In dié tyd beleef die Seleukiede interne onstabiliteit, sowel as eksterne dreigemente van die Partiërs en Ptolemeus VI Philopater (181-146 v.C.). Antiochus besef dat dit nodig is om sy koninkryk te verenig en voorspoed te skep. Sy broer se oorlog teen Egipte het ernstige finansiële probleme veroorsaak.

Hy bemagtig stede om Griekse poleõs te word, met gimnasia en Griekse skole, waar Zeus en ander Griekse gode aanbid word. Plaaslike gode word in dié proses met die Griekse pantheon geïdentifiseer (LaCocque, 1988:26). In Jerusalem ondersteun baie invloedryke Jode die hellenisasiebeleid.

Die hoëpriesterpos is vakant, aangesien Onias homself by die koninklike hof verdedig. Josua (hyself verkies die Griekse weergawe van sy naam, Jason) belowe om 'n groot bedrag te betaal as Antiochus hóm aanstel as hoëpriester. Die koning doen dit sonder om hom te steur aan die oorerflike opvolgreg.

Jason kry ook toestemming om 'n gimnasium in Jerusalem te begin - 'n assosiasie van hellenistiese Jode met definitiewe wetlike en burgerlike regte (1 Makk. 1:12-15; 2 Makk. 4:12-16). Griekse sport is onafskeidbaar deel van die Herakles- en Hermeskultus. Griekse gebruike en modes word nou die norm in Jerusalem. Omdat Grieke besnydenis as ontmanning beskou het, en deelnemers in sport naak is, het Joodse manne hulle besnydenis ongedaan gemaak (LaCocque, 1988:18; 1 Makk. 1:15). "How far the Jews could collaborate with Roman power, how much they could compromise with 
Hellenistic culture and still remain true to Yahweh and his Law, was the agonizing question they encountered daily" (Cantor, 1994:36).

Menelaus se aanbod om hoëpriester te word, is hoër as Jason s'n. Jason vlug vir sy lewe (2 Makk. 3:4; 4:23). Menelaus steel tempelvoorwerpe om sy aanbod te finansier. As Onias, wat nog in Antiochië is, hieroor beswaar aanteken, word hy geëlimineer. Opponente van die helleniseringsbeleid beskou Onias as ' $n$ martelaar.

In 169 v.C. kom Antiochus terug van 'n suksesvolle aanval op Egipte (Herrmann, 1973:357). Hy plunder die Jerusalemtempel en konfiskeer die tempel se waardevolle voorwerpe ná 'n gerug dat hy in Egipte dood is, en Jason Jerusalem met duisend man binneval (2 Makk. 5:5-10). Jason vlug en sterf in Sparta.

In 168 v.C. verower Antiochus weer grondgebied in Egipte, maar hierdie keer stel Popilius Laenas 'n ultimatum van die Romeinse senaat aan hom, wat hom beveel om Egipte te verlaat. Op sy terugtog en in 'n slegte bui, hoor hy dat Jerusalem sy beleid weerstaan en dat sy verteenwoordigers mishandel word. Dit lei tot die eerste pogrom in die Joodse geskiedenis (LaCocque, 1988:27). Apollonius kom vroeg in 167 v.C. onder vals voorwendsel en val die stad op 'n Sabbatdag binne. Baie Jode sterf en ander word gevange geneem. Die stad word geplunder en die mure afgebreek. Op die plek waar Dawid se paleis was en in die omliggende dele van die tempel, bou die Siriërs nou die Akkra, 'n vesting vir Siriese soldate. Antiochus proklameer die tempel as heiligdom van die nuwe stadstaat, Akkra. Judaïsme word geherorganiseer as 'n Siro-hellenistiese kultus. Die tempel word gewy aan die koninklike kultus van Zeus Epifanes (Dan. 9:27; 12:11 verwys na dié kultus). Offers word verbied (Dan. 8:11-12; 11:31-35). Gelowige Jode moet besluit tussen lojaliteit aan JHWH of die Siriese koning.

Die ontheiliging van die tempel lei tot 'n Joodse rebellie, wat op sy beurt tot Antiochus se finale vernietigende maatreëls lei. Niemand mag meer die Sabbat of enige godsdienstige fees onderhou nie. Die besit van die heilige Skrifte en die besnydenis is strafbaar met die dood. Jode word verplig om varkvleis te eet en selfs ook varke op die tempelaltaar te offer. Hulle moet ook die koning se verjaarsdag vier, deur maandeliks offers in die tempel te bring. Antiochus kry nou die bynaam, Epimanes ("malman"), onder die Jode (Le Roux, 1995:xv).

Caragounis (1993:396) noem dat "from the Greek point of view Antiochus IV was not merely an astute, capable and enlightened 
monarch, he was even a good king". Al wat hy wou doen, was om sy onderdane te verenig. So het hy die Samaritaanse tempel aan Zeus Xenius gewy, op versoek van die Samaritane. Sommige Jode het die identifikasie van JHWH met Zeus verwelkom. Ander het egter enige kompromis as ' $n$ aantasting van die uniekheid van Israel se verhouding met JHWH beskou.

Hanson (1976:30-31) beskryf twee groepe as kenmerkend van die getroue gelowige Jode in Antiochus se tyd. Die priesterlik-teokratiese groep het probeer om Israel se ideale in die geskiedenis te realiseer. Hulle droom van 'n onafhanklike Joodse staat en tempel. Die profetiese-eskatologistiese groep vertrou egter nie die historiese faktore en prosedures nie, maar wag vir die ingrype van God in die geskiedenis, wat 'n einde aan die geskiedenis sal maak as Hy sy ewige koninkryk vestig, soos Daniël 2 dit verwag.

\section{Vyandigheid as 'n belangrike onderwerp in die boek van Daniël}

\subsection{Vyandigheid tussen God en die mens}

Die apokaliptiese skrywer(s) van die Daniëlboek sien slegs een groep mense wat die seën van God geniet, omdat hulle in die regte verhouding met Hom lewe. Dié groep is die maskilim of wyses, en die hasidim of regverdiges. Daniël 11:30 beskryf hulle as "die heilige verbond", die mense teen wie Antiochus sy maatreëls instel. Vers 32 beskryf hulle as "die mense wat hulle God ken", wat standvastig teen die Siriese koning bly staan. Vers 33 noem dié leiers van die groep "verstandige leiers" of wyses, wat leiding aan baie mense sal gee, of instruksie of begrip sal bring. Party van "die wyses" (maskilim) sal struikel, sodat hulle gesuiwer en gereinig kan word (v. 35). Dit is die mense wat in die "beloofde land" (v. 41), die pragtige land, woon. In Daniël 12:1 beskryf Migael hulle as "jou (Daniël se) volk", die Jode.

Baie van dié wat gesterf het, sal opstaan, party tot die ewige lewe en party tot ewige verderf en skande. Hierdie is die enigste duidelike verklaring van geloof in die opstanding van die dood, in die Hebreuse Bybel. Dat die teks na baie en nie na alle Jode nie verwys, hou waarskynlik verband daarmee dat die groep beperk word tot die gelowiges, "die mense wat hulle God ken". Die verwysing is ook moontlik na mense wat vir hulle geloof gesterf het, as martelare. Wie is die mense wat opstaan tot die ewige verderf en skande? Indien die verwysing na martelare is, dan is die ander groep waarskynlik die mense wat instrumente daartoe was dat die 
eerste groep vir hulle geloof doodgemartel is. Die martelare is mense wat hulle verbintenis met die God van Israel bevestig deur die nakoming van die Tora. Rabbim kan egter ook gebruik word in die sin van "almal", wanneer die klem val op die hoeveelheid wat daarby betrokke is, soos Jeremias (1968:536-545) aandui.

Die wyse of verstandige leiers sal skitter met die glans van die hemel self, en dié wat baie mense op die regte pad gelei het, sal vir altyd skitter soos die sterre (v. 3). "Die wyses" is duidelik 'n groep wat goed opgelei is in die Joodse skrifte and wat, op grond van hierdie basis, begryp wat God se weg met die geskiedenis is en weet hoe om te reageer in die krisissituasies. Die woord wat vir "begryp, verstaan" (byn) gebruik word, kom algemeen in Daniël voor om insig aan te dui in die sin van drome, openbarings en profesieë. Die vorm waarin die Daniëlboek oorgelewer is, ontstaan in die geledere van hierdie groep, die maskilim en hasidim, en verteenwoordig dié soort begrip wat aan die "baie" meegedeel moet word. Die "baie" verwys na die Jode wat gekies het om nie aan Antiochus se edikte gehoor te gee nie. Die boek waarsku hulle dat hulle verseker vir hulle standvastigheid vervolg sal word. 6

Wie is die "wyse/verstandige"? Die debat hieroor duur al baie lank, omdat die antwoord die sleutel bied om te verklaar wie in die kringe is waarbinne die Daniëlboek ontstaan het. Verskeie oplossings is voorgestel, waarvan die belangrikstes die volgende is:

- Die Hasidim van 1 Makkabeërs 2:42; 7:12 e.v. en 2 Makkabeërs $14: 6$ - 'n vroom groep wat oorspronklik deel is van die Makkabese opstand, maar mettertyd ontnugter, ontgogel en teleurgestel raak, en hulle terugtrek.

- Die mense wat "soek na geregtigheid en reg", soos beskryf in 1 Makkabeërs 2:29-38 - wat na die wildernis gegaan het met hulle families en besittings om weg te kom van hulle vervolgers en om daar streng volgens die Tora te leef.

- Heaton (1956:19-24) verbind hulle aan 'n groep rondom Jesus ben Sirag, skrywer van Ecclesiasticus, 'n skrifgeleerde.

$6 \quad$ Ginsberg (1953:403) het reeds geargumenteer dat die skrywer 'n doelbewuste verbintenis maak tussen "die wyse" en "die dienskneg van JHWH". Die begrippe "die wyse/verstandige" en "baie" kom ook voor in die laaste Dienskneglied (Jes. 52:13; 53:11). 
- Sommige navorsers meen dat "die wyses" die voorlopers van die Qumramgemeenskap was.

- Lucas (2002:289) wys op die verbintenis tussen Daniël 12:10 en $1: 4$, waar die woorde "verstandige" en "verstandig" voorkom. "Die wyse" is na sy mening 'n groep hoër klas, goed-opgeleide Jode wat daarna streef om getrou aan hulle God te bly, terwyl hulle as administrateurs in buitelandse politieke stelsels diens doen. Hulle bestudeer die Skrifte om te probeer verstaan hoe om getrou te bly te midde van 'n heidense konteks. Hulle blootstelling aan die heidense wêreld kan gesien word in die diere-beeldspraak en mitologiese sinspelings van Daniël $7-8$, en die vorm van die profetiese oorsig van die geskiedenis wat in Daniël 11 voorkom.

- Daar is ten minste twee groepe wat in vyandskap met God lewe, vanuit die perspektief van die Daniëlskrywer. Die eerste groep is Jode wat hulle geloof versaak het in 'n poging om die vervolging onder Antiochus vry te spring. Baie van die progressiewe Jode het Antiochus se hellenisasiebeleid ondersteun en gemeen dat dit groot voordele vir die Jode inhou. As rabbîm só geïnterpreteer word dat dit verwys na "almal", die hele volk van die verbond, word die oordeel van "ewige skande en veragting" (12:2) toegepas op hierdie groep, die kompromitterendes. Die ander groep wat vyandig teenoor die God van Israel staan, is die heidense nasies, soos verteenwoordig deur hulle konings en die verwoesting wat hulle in Israel indra. Wanneer die konings veroordeel word, sluit hulle oordeel by implikasie ook die nasies in. Interessant is die opmerking in Daniël 11:41 dat Edom, Moab en die leiers van Ammon Antiochus se mag sal ontvlug - sekerlik nie omdat hulle nie God se oordeel verdien nie, maar as gevolg van die historiese feit dat Antiochus nie hulle gebied binnegeval het nie.

\subsection{Vyandigheid tussen die Jode en buitelandse konings}

In die verhale word die verhouding tussen Daniël en sy drie vriende, en die buitelandse konings baie vriendelik en ontspanne geteken. Die Jode werk saam met die koning, behalwe waar hulle lojalitiet aan die koning hulle godsdiens en etiese beginsels kompromitteer. Dit is die rede dat die verhale in die tweede-eeuse konteks herhaal word - juis om die gevare uit te wys dat Jode hulle geloof kon kompromitteer. As Daniël en sy vriende nie die koning se kos wou eet nie (Dan. 1), hoeveel te meer moet Jode weier om onrein varkvleis in opdrag van Antiochus te eet? As Daniël weier om voor die koning se beeld te kniel en dit te aanbid (Dan. 6), hoeveel te 
meer moet die Jode weier om Zeus se beeld te aanbid wat in die tempel opgerig is. Die geloofsverklaring van die drie jong vriende in Daniël 3:16-18 moedig die Jode aan om God te vertrou, selfs al kos dit hulle lewens. Die vierde een in die brandende oond, is soos 'n seun van die gode (Dan. 3:25). Die verhale van die arrogante Nebukadnesar wat strooi soos 'n dier eet (Dan. 4) en Belsasar se visioen van die skrif teen die muur (Dan. 5) moedig Jode aan om in dié God te glo wat konings aanstel of afdank (Dan. 2:20). Die geskiedenis van die wêreld word op so 'n wyse geskilder (Dan. 2) dat Jode hulle God sal sien as die Een wat besluit oor die lot van konings en mense.

Dit beteken nie dat die heidense konings, volgens hierdie verhale, vir die Jode erge pyn en trauma veroorsaak het nie. Die Babiloniese koning het immers Jerusalem verower, talle Judeërs weggevoer en die tempelskatte gekonfiskeer. Maar dit is $\mathrm{YHWH}$, beklemtoon Daniël 1:2, wat Jojakim en 'n deel van die tempelgereedskap, asook die stad en sy mense oorgee in die hande van Nebukadnesar. In Daniël 2 dreig die koning om die wyse manne dood te maak as hulle nie sy droom kan uitlê nie. Darius beveel ook dat niemand vir dertig dae lank aanbid mag word nie, behalwe hyself.

In Daniël 4 en 5 word die arrogansie en hubris van die heidense konings gedemonstreer vanuit 'n alternatiewe standpunt, wanneer die God van Israel kommentaar lewer deur hulle te verneder.

In die visioene is die verhouding tussen die Jode en die koning baie meer gespanne. Dit is een van die redes waarom die verhale vóór die openbarings gedateer word. Die verhale is vertel om die Jode te waarsku daarteen dat hulle nie hulle geloof moet kompromitteer nie, terwyl die visioene in die tyd ontstaan wanneer die Jode se verhouding met Antiochus hoogs gespanne is.

Die heidense konings word hier voorgestel as aggresiewe, vernietigende diere (Dan. 7:3) Die koning, verteenwoordig deur die vierde dier - skrikwekkend, vreesaanjaend en baie sterk - se horing plaas 'n verbod op die daaglikse offerandes, en vertrap die heilige plekke (Dan. 8:9-11). Hierdie koning verhef homself bo elke god, en selfs teen die ware God sê hy "ongehoorde dinge" (Dan. 11:36).

Die koning sal verseker nie die goddelike straf vryspring nie. Die Oue van dae, Hy wat ewig lewe, gaan sit op die regsbank en 'n stroom vuur kom uit sy mond. Die hofsitting vind plaas en die boeke word geopen (Dan. 7:9-10). Agter die skerms bepaal engele wat in 
die wêreld se geskiedenis plaasvind (bv. Dan. 10:13-14). 'n "Boek van die Waarheid" bepaal die geskiedenis (Dan. 10:21).

\subsection{Vyandigheid tussen Jode en hulle bure}

In die verhale is daar nie openlike vyandigheid tussen die Jode en hulle oorwinnaars nie. $\mathrm{Na}$ alles gee JHWH, die God van die Jode, die Jode en hulle tempel in die hande van die Babiloniese koning oor (Dan.1:2).

Met die visioene verander die atmosfeer dramaties. Hier word die buitelandse magte sonder uitsondering in vyandige terme beskryf, as afbrekend en arrogant.

Die vyandigheid word ook hier opgelos deur goddelike ingrype. Een soos die seun van die mens ('n menslike wese), word voorgestel aan die Oue van dae, die Een wat ewig lewe, wat aan hom heerskappy, eer en koningskap gee. Alle volke, nasies en taalgroepe dien hom en sy heerskappy is ewig, sodat dit nie tot niet gaan nie (Dan. 7:13-14). Die verwysing na "seun van die mens" kom ook voor in Daniël 8:15 en 10:16, 18, waar engelfigure in menslike gestalte so voorgestel word.

In Esegiël word die profeet drie-en-negentig keer aangespreek as ben 'ādām. Die Aramese frase wat hier gebruik word, bar 'ənôš, kom in die middel van die agtste eeu v.C. voor in die derde Sefirestele. Daar verwys dit na "iemand" of "n persoon" (Lucas, 2002:184). Later word "seun van die mens" 'n titel van 'n individu in 1 Henog 37-71. Vergelyk ook die verwysing in Esdras 4/Esra 13, asook in die Nuwe Testament, waar Jesus so na Homself verwys. Die verwysings wat gebruik word dui dat Daniël 7:13 as interteks gebruiklik is. Die latere gebruik mag egter nie teruggelees word na dié frase in Daniël nie. Wat Daniël sien, is bloot "een soos 'n menslike wese" (Lucas, 2002:184). Dieselfde voorsetsel, "soos", kom ook voor wanneer die eerste en derde dier beskryf word. Daar word die ooreenkoms gekwalifiseer deur die volgende frase. Hier is daar nie so 'n frase nie, behalwe as dit verwys na die voorafgaande frase, "met die wolke van die hemel". Collins (1993:305) kom tot die gevolgtrekking dat "soos" in 7:13 "is best understood as indicating the mode of perception proper to a vision, so that 'like a son of man' means 'a human figure seen in a vision', where the figure may or may not represent something other than a human being". Die ooreenkoms met die gebruik van hierdie frase wat die diere beskryf, dien ongetwyfeld as 'n kontras tussen hierdie figuur en die diere. Die 
figuur funksioneer as 'n simbool van God se regering wat in die wêreld deurbreek (Lucas, 2002:185). ${ }^{7}$

\subsection{Vyandigheid tussen gelowige Jode en Jode wat kompromieë aangegaan het}

Daar is reeds verwys (in 3.1) na die twee groepe Jode wat deur die skrywer(s) van Daniël veronderstel word, naamlik die getroues en die kompromitteerders. Die eerste groep is "die wyses", mense wat hulleself rein hou en die inhoud van die visioene verstaan (Dan. 12:10). Die ander groep is "die bose", wat nie die visioen verstaan nie en sondig optree.

Die vyandigheid tussen dié twee groepe word nie in die Daniëlboek opgelos nie, behalwe in terme van die oordeel wat aan die einde van die tyd voor God se troon plaasvind.

\subsection{Gevallestudie: Daniël in die leeukuil (Dan. 6)}

Die komplot in Daniël 6 word bepaal deur die politieke ampsdraers in Darius se hof - amptenare wat jaloers is op Daniël se politieke suksesse. Hulle vind geen grond vir enige aantygings van swak gedrag of nalatigheid teen Daniël nie, omdat hy betroubaar is in alles wat hy doen. Hulle besef dat hy slegs aangekla sal kan word op grond van sy lojaliteit teenoor sy God, en die wette van hierdie God. Hulle versoek die koning om 'n wet uit te vaardig dat niemand enige petisie tot enige god mag rig nie, behalwe tot die koning. Enigeen wat ongehoorsaam is hieraan, moet in die leeukuil gegooi word. Koning Darius teken die geskrewe verbod, en verseël sodoende Daniël se lot.

Daniël bid drie maal elke dag met sy vensters oop na Jerusalem. Die vyande kla Daniël, "een van die Judese ballinge", voor die koning aan (v. 13/14 in onderskeidelik Hebreeuse en Griekse tekste). As die koning probeer om uitstel te vind, met die doel om Daniël te probeer red, herinner sy amptenare hom daaraan dat 'n wet van die Mede en Perse nie herroep kan word nie. Die koning gooi Daniël in die leeukuil met die woorde, "Mag die God wat jy met

$7 \quad$ Nie alle kommentatore stem saam nie. Verskeie interpretasies vir "die seun van die mens" is al aangebied. Die belangrikste is: 'n messiaanse figuur; Christus; God se uitverkore volk; Judas Makkabeus; Daniël self; die Joodse volk; engelewesens; Gabriël en Migael. Vgl. LaCocque (1979:133); Collins (1993:310); Goldingay (1993:172); Lederach (1994:162) en Dunn (1997:200203). 
soveel volharding dien, jou red" (v. 16/17). Vroeg die volgende môre haas die koning hom na die leeukuil en vra, "Daniël, dienaar van die lewende God, was jou God wat jy met soveel volharding dien, in staat om jou van die leeus te red?" Daniël antwoord dat sy God 'n boodskapper, 'n engel gestuur het om die bekke van die leeus te sluit, sodat sy onskuld bewys mag word. Die koning gooi dan Daniël se vyande saam met hulle vroue en kinders in die leeukuil. Voor hulle die grond raak, oorweldig die leeus hulle en verskeur hulle. Hierdie ondervinding lei daartoe dat die koning 'n brief aan al sy onderdane skryf, waarin hy bevel gee dat almal onder sy bevel die God van Daniël moet eerbiedig en vrees, omdat Hy Daniël uit die mag van die leeus gered het.

Kenmerke van dié verhaal is dat minder gesprekke as in die ander verhale woordeliks weergegee word; die herhaaldelike gebruik van die verbinding bē'dayin (vyftien keer); 'n chiastiese struktuur wat Daniël se redding beklemtoon, en veral dat die redding wat Darius begeer, maar nie kan doen nie, God doen (Goldingay, 1989:124); die herhaling van sleutelwoorde om belangrike aspekte van die verhaal te beklemtoon; subtiele woordespel (Arnold, 1993:483); en die herhaalde gebruik van hendiadys (bv. in v. 4, 7, 8, 9, 10, 11 en 15).

"Wet" (dāt) is 'n sleutelwoord in die verhaal. Op een vlak is die verhaal oor die eise wat die "wet van sy God" aan Daniël stel (v. 5/6), teenoor die eise van die "wet van die Mede en Perse". Op 'n ander vlak gaan dit om die koning, wie se goddelike aspirasies deur sy raadgewers uitgebuit word. Hy word geflous om 'n wet te maak wat homself in 'n valstrik laat beland, terwyl die Jode se God daardie wet oneffektief maak (Fewell, 1991:109-111).

Volgens Lucas (2002:154-155) ondermyn die verhaal die absolutistiese eise van aardse magte op twee maniere. In die eerste oogopslag mag dit lyk asof Daniël, wat aanhou bid, onskuldig is, maar dit is meer "revolutionary than outright rebellion would have been" (Wink, 1984:110-111). Opstand poog om die absoluutheid van die koning se mag te gryp. Gebed ontken daardie absoluutheid, deur 'n hoër mag te erken. In die tweede plek is die ironiese feit, dat die samesweerders die koning se semi-goddelike status in hulle eerste gesprek met hom erken, terwyl die leser die koning sien as 'n liggelowige, sterflike wese, wat deur sy amptenare gemanipuleer en misbruik word vir hulle eie doelwitte. In die tweede gesprek wat hulle met die koning het, gebruik hulle dieselfde wet wat die koning se semi-goddelike status erken, om die koning in 'n vangstrik te kry en hom te dwing om te doen wat hy nie wil nie. "His attempt to claim 
absolute power makes him a puppet of his officials and a dupe of his own law" (Lucas, 2002:155).

Op hierdie wyse beklemtoon die verhaal nie dat God altyd die onskuldiges en getroues red van martelaarskap nie, maar dat Hy aan hulle oorwinning van lewe bo dood, hoop bo vrees, en die goeie bo die bose gee. Daardie oorwinning is selde in die vorm van wonderwerke van fisiese redding, wat beklemtoon dat toevallige ondervindings van goddelike ingrype, meer werd is as gereelde ondervindings van goddelike nie-ingrype (Goldingay, 1989:133-134). "In telling these stories today, the church must exercise extreme caution less the relationship with God is reduced to a triumphal, commercial transaction: if you do this, then God will do that! ... When God intervenes it is to accomplish his purposes, not ours" (Lucas, 2002:155).

\section{Samevatting}

'n Oorsig van die Daniëlboek wys dat vyandigheid 'n belangrike onderliggende tema is wat die verhale (Dan. 1-6) asook die gang van die visioene (Dan. 7-12) bepaal. Vyandigheid bestaan in die oë van die skrywer van die Daniëlboek tussen God en sommige Jode, wat ' $n$ kompromis in hulle geloof en kultuur met Antiochus se hellenisasiebeleid aangegaan het, sowel as tussen God en buitelandse konings, wat sy volk se land ingeval het en die mense van die verbond onderdruk. Dat sy volk onderdruk word, hou verband daarmee dat Hy hulle in die hand van die vreemde konings gegee het. Hierdie konings, en hulle onderdane in afgeleide sin, sal deur God geoordeel en gestraf word. Hierdie mense is die Jode se vyande. Al kan hulle nie hulleself verdedig teen hierdie magte nie, word die Jode bemoedig deur die visioene wat God se mag agter die skerms bewys, om te verseker dat sy regverdigheid seëvier.

Nog 'n lyn van vyandigheid kom voor tussen twee groepe Jode, die mense wat getrou bly, volgens die definisie wat gebruik word deur die apokaliptikus, en die kompromitterende groep. In hierdie geval, soos in die geval van vyandigheid tussen God en mense, en Jode en hulle vyande, word die oordeel en straf aan God oorgelaat. Aan die einde besluit Hy oor mense. Die vyandskap word opgelos in die opstanding en oordeel, wat daartoe lei dat sommige mense ewig lewe, terwyl ander met die ewige skande en die verdoemenis gestraf word.

Die gevolgtrekking is dat die apokaliptiese literatuur in die Daniëlboek impliseer dat vyandskap deel van die lewe van Israel is, en 
slegs uiteindelik opgelos word in die apokaliptiese einde van die wêreld soos ons dit ken.

\section{Geraadpleegde bronne}

AHLSTRÖM, G.W. 1993. The history of ancient Palestine from the palaeolithic period to Alexander's conquest. Journal for the Study of the Old Testament-supplement, 146. Sheffield: JSOT.

ALBERTZ, R. 2003. Israel in exile: the history and literature of the sixth century BCE Leiden: Brill.

ARNOLD, B.T. 1993. Wordplay and narrative techniques in Daniel 5 and 6. Journal of Biblical Literature, 112: 479-485.

CANTOR, N.F. 1994. A modern history of the Jews. New York: Lang.

CARAGOUNIS, C.C. 1993. History and supra-history: Daniel and the four empires. (In Van der Woude, A.S., ed. The book of Daniel in the light of new findings. Leuven: Leuven University Press. p. 387-398.)

COLLINS, J.J. 1993. Daniel: a commentary on the book of Daniel. Hermeneia. Minneapolis: Fortress.

DUNN, J.D.G.1997. "Son of God" as "Son of man" in the Dead Sea Scrolls? A response to John Collins on 4Q246. (In Porter, S.E. \& Evans, C.A., eds. The scrolls and the Scriptures: Qumran fifty years after. Sheffield: Sheffield Academic Press. p. 198-210.)

FEWELL, D.N. 1991. Circles of sovereignty. Nashville: Abingdon.

GINSBERG, H.L. 1953. The oldest interpretation of the Suffering Servant. Vetus Testamentum, 3:400-404.

GOLDINGAY, J.E. 1989. Daniel. Dallas: Word.

GOLDINGAY, J.E. 1993. Story, vision, interpretation: literary approaches to Daniel. (In Van der Woude, A.S., ed. The book of Daniel in the light of new findings. Leuven: Leuven University Press. p. 295-314.)

GRAYSON, A.K. 1975. Assyrian and Babylonian chronicles, 100. Locust Valley: Augustin. (TCS, 5.)

HANSON, P.D. 1976. "Apocalypticism". (In Crim, K., ed. Interpreter's dictionary of the Bible. Supplementary Volume. Nashville: Abingdon. p. 28-34.)

HEATON, E. 1956. Daniel. London: SCM.

HERRMANN, S. 1973. A history of Israel in Old Testament times. Revised edition. Translated by J. Bowden. London: SCM.

JEREMIAS, J. 1968. "Polloi". (In Kittel, G. \& Friedrich, G., eds. Theological dictionary of the New Testament. Grand Rapids: Eerdmans. p. 6:536-545.)

LACOCQUE, A. 1988. Daniel and his time: studies of personalities of the Old Testament. Columbia: University of South Carolina Press.

LE ROUX, C. 1995. Profeet en politiek: Daniël: die woord vir die mense. Halfway House: Orion.

LE ROUX, J.H. 1988. Eschatology and the prophets: a survey of the research. Old Testament Essays, 1(1):1-26.

LEDERACH, P.M. 1994. Daniel. Scottdale: Herald.

LUCAS, E.C. 2002. Daniel: Apollos Old Testament commentary. Leicester: Apollos.

RENDTORFF, R. 1985. The Old Testament: an introduction. Translated by J. Bowden. London: SCM.

SOGGIN, J.A. 1984. A history of Israel: from the beginnings to the Bar Kochba Revolt, A.D. 135. London: SCM. 
VENTER, P.M. 1997. Daniel and Enoch: two different reactions. Hervormde Teologiese Studies, 53(1-2):68-91.

WINK, W. 1984. Naming the powers. Philadelphia: Fortress.

\section{Kernbegrippe:}

apokaliptiek

oordeel en straf

vyandigheid

\section{Key concepts:}

animosity

apocalypticism

judgement and punishment 